COMPETITOR: Jurnal Pendidikan Kepelatihan Olahraga

Volume 13 Number 2 Year 2021

e-ISSN: 2657-0734 \& p-ISSN: 2085-5389

This work is licensed under a Creative Commons Attribution 4.0 International License

\title{
Improve Learning Outcomes of Basketball Lay Up Shoot in Junior High School
}

\author{
Muhamad Syamsul Taufik ${ }^{1^{*}}$, Soleh Solahuddin ${ }^{2}$, Arisman $^{3}$, Azi Faiz Ridlo ${ }^{4}$, Tatang Iskandar ${ }^{5}$ \\ ${ }^{1}$ Physical Education, Health and Recreation, Faculty of Teacher Training and Education, \\ Suryakancana University, Cianjur, West Java, Indonesia \\ Street. Dr. Muwardi Pasir Gede Raya Complex Tel. (0263) 262284 Cianjur, West Java, 43216 \\ ${ }^{2}$ Physical Education, Health and Recreation, Faculty of Teacher Training and Education, \\ Sriwijaya University, Ogan Ilir, South Sumatra, Indonesia \\ Street. Palembang - Prabumulih KM.32 Ogan Ilir Regency, South Sumatra \\ ${ }^{3}$ Sports Coaching Education, Faculty of Teacher Training and Education, Mitra Karya University, \\ Bekasi, West Java, Indonesia \\ Street. Major Madmuin Hasibuan No. 5, RT.006/RW.008, Margahayu, Kec. East Bekasi, Bekasi, West \\ Java 17113 \\ 4,5 Physical Education, Health and Recreation, Faculty of Teacher Training and Education \\ 45 Islamic University Bekasi, West Java, Indonesia \\ Street. Cut Meutia No. 83, Bekasi, West Java 17113

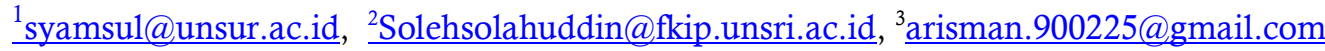 \\ azifaizridlo@unismabekasi.ac.id ${ }^{5}$ tatang@unismabekasi.ac.id
}

Received: April 4, 2021; Reviewed: May 11, 2021; Accepted: May 15, 2021;

Published: June 18, 2021

\begin{abstract}
This research is motivated by the fact about the lack of student grades in the practice of lay up in basketball lessons. The purpose of this research is to be able to improve the learning outcomes of basketball lay up basketball in class VII-8 students at SMP Negeri 1 Ciawi through the section method. The method used is a classroom action research method. The research subjects were students of class VII-8 Ciawi Public Middle School, which consisted of 14 male students and 18 female students, with a total of 32 students. The results of the research analysis showed that there was an increase in basketball lay-up technique skills in the VII-8 grade students of SMP Negeri 1 Ciawi through the method section. In the first cycle, the percentage score for student observations was $71.8 \%$, while in the second cycle the percentage score for student observations was $88.15 \%$. This improvement is caused by each individual during the learning process using the section method to improve their basketball lay-up technique skills to students.
\end{abstract}

Keywords: Basketball; Education; Junior High School.

\section{INTRODUCTION}

Education is something important in people's lives. Education is an effort carried out in a structured and logical manner that aims to foster and build a person into a more 
Improve Learning Outcomes Of Basketball Lay Up Shoot In Junior High School

Muhamad Syamsul Taufik ${ }^{1 *}$, Soleh Solahuddin ${ }^{2}$, Arisman $^{3}$, Azi Faiz Ridlo ${ }^{4}$, Tatang Iskandar ${ }^{5}$

syamsul@unsur.ac.id

mature person so that he can make wise decisions and have an impact on the educational needs of life in society. Education is a process of human development that lasts a lifetime. (Taufik, 2018). Physical education is an important part of human development to achieve overall educational goals. Therefore, physical education is not only a means of supporting education but also realizing national development. In the school's physical education curriculum, gymnastics dominates the learning material (PERMENDIKBUD NO 37, 2018). Learning outcomes are the ability of students after gaining experience during the learning process. According to Bloom's theory, learning outcomes are divided into three domains, namely the cognitive, affective and psychomotor domains. Although this sport is a complex physical activity, including "close skills, open skills and a combination of skills" not even all children are ready to accept it, for this reason, development and modification of learning are very important to achieve the expected learning objectives.

In sports, some sports can be played by the community both in the village and in the city and even in schools and institutions. The game of basketball is now starting to be loved by the people of Indonesia, with basketball championships such as DBL, Campus League, WNBL, NBL, etc. Increase public interest in learning basketball and participating in championships. Almost the whole world knows and plays this basketball sport, especially in North America, China and also the European continent. Not to forget, women do not want to be left behind in the field of basketball. It can be said that this sport is very popular and is known by all circles.

(Haqiyah et al., 2017) In this study, to overcome this problem based on the importance of the teacher's role in the learning process and its relation to the activation of students in learning and the importance of providing auditory, vision and workmanship stimuli, development research is needed to improve learning achievement According to (Widiastuti \& Pramudito Hutomo, 2018) The problem faced by researchers is that the PJOK teachers who teach at the school do not use teaching aids, so the factors that hinder students in learning.

This basketball game is very interesting because it can be played by all ages. In addition, players are required to play skills, physical freshness and high endurance. Basketball is a game played by two teams of 5 players each. The goal of both teams is to get points by getting the opponent's ball and prevent the opponent from getting the ball into our cart. Basketball games are supervised by an official (referee), a table clerk and a Commissioner (supervisor). 
Improve Learning Outcomes Of Basketball Lay Up Shoot In Junior High School

Muhamad Syamsul Taufik ${ }^{1 *}$, Soleh Solahuddin ${ }^{2}$, Arisman $^{3}$, Azi Faiz Ridlo ${ }^{4}$, Tatang Iskandar ${ }^{5}$

syamsul@unsur.ac.id

(Fadillah et al., 2020) The progress of sports is also influenced in terms of facilities, external constraints such as physical education facilities and infrastructure in schools are very minimal so that it becomes an obstacle, this is where teachers are tested as facilitators in the learning process. To increase access to and achievement in basketball learning, many factors are related. At this time the learning of basketball material at SMP Negeri 1 Ciawi has not fully gone well, so that learning achievement and achievement is not as expected, to achieve this, things such as interests, talents, physical conditions, facilities, infrastructure, and training system called method. (Prasetya et al., 2018) Physical education emphasizes holistic aspects of education (health, physical fitness, critical thinking skills, emotional stability, social skills, reasoning and moral action). (Ahmadi, 2007) (Izhar, 2018) From several theories about Physical Education it is clear (Yuniarto et al., 2018) that the realm of physical education is not only about psychomotor, moreover physical education involves affective and psychomotor domains. Children as a process in which individuals acquire optimal physical, mental, social and fitness skills through physical activity enhance the growth and development of all domains, physical, psychomotor, cognitive, and affective of each student. (Jatmika, 2015) The development of aspects of these learning activities will of course be designed so that everything goes according to the objectives of the learning process that have been set for each subject. Physical education is one of them. According to (Ambarwati et al., 2017) the basic techniques contained in the basketball game Motor ability is an ability possessed by a person related to the implementation of physical abilities to be able to perform a movement, or it can also be defined that motor skills are the ability to perform in performing a movement. movement. Because in (Hambali, 2019). In the basket game, players are required to master good basic techniques, therefore players must also have good movement skills. Sport is an activity that prioritizes physical processing (Rahadian, 2018). Movement skills are the ability to perform movements efficiently and effectively. Movement skills The equipment used can be reduced or added to the level of complexity and difficulty using modification. For example, the size, weight, light, height, and height of the equipment to be used. (Ganang Purnomo Aji, 2016) This learning gives students the freedom to move as widely as possible. By using a modified tool, it is hoped that it can eliminate fear, torment, boredom and boredom in students so that students have a sense of independence and responsibility in determining and making decisions. 
Improve Learning Outcomes Of Basketball Lay Up Shoot In Junior High School

Muhamad Syamsul Taufik ${ }^{1 *}$, Soleh Solahuddin ${ }^{2}$, Arisman $^{3}$, Azi Faiz Ridlo ${ }^{4}$, Tatang Iskandar ${ }^{5}$

syamsul@unsur.ac.id

\section{METHOD}

This research uses classroom action research. The method used in this research is Classroom Action Research. Classroom action research is research on learning activities in the form of deliberate actions that occur in class together. By (Gall et al., 2003) using a research design model of Kemmis and Mc. Taggart is in the form of a cycle or round of activities which includes the stages of 1) planning (planning), 2) action (action), 3) observation (observing) 4) reflection (reflection), in each round. (Saputri et al., 2013) In this study, the role of the researcher as a physical education teacher is as a key instrument, researching, and directly involved in the entire research process, from activity planning to the reflection stage. in each cycle. In addition, researchers act as planners, observers, processors, and data analyzers, so to prove the objectivity of research documents such as results of actions and test results need to be attached. The research method used is qualitative and quantitative. Qualitatively explain the events carried out in this research to get a complete picture and explanation in the implementation of action research. descriptive and inferential statistics to test research hypotheses with the help of the SPSS program with a significant level of $95 \%$ or $=0.05$. Data analysis was done descriptively and inferentially to test the research hypothesis. Population and Sample: This research was conducted at SMP Negeri 1 Ciawi, which is located in Bogor District, Bogor Regency. This research was conducted in the middle of the even semester of the 2018-2019 school year, from March to May 2019. The research time refers to the school's academic calendar, the school's annual program and the school semester program. In this classroom action research, the subjects are class VII-8 students from the entire population of class VII at SMP Negeri 1 Ciawi for the academic year 2019-2020 with a total of 32 students, consisting of 14 male students and 18 female students. Documentation, and observation. Data analysis was carried out descriptively by comparing the results of achievement with indicators of success. Design or Quantitative Data Analysis is used to analyze teaching and learning outcomes data or compares student scores before and after action research is carried out. The value will be tested for accuracy through this method to see how big the value is before and after it is done. Students try to get as many balls as possible into the basketball hoop within 1 minute. The calculation of the score is done by getting a score of 1 if the student makes the lay-up shoot movement correctly and the ball goes in. Get a score of 0 when students dribble (double, travelling) or the ball doesn't go in. 
Improve Learning Outcomes Of Basketball Lay Up Shoot In Junior High School

Muhamad Syamsul Taufik ${ }^{1 *}$, Soleh Solahuddin ${ }^{2}$, Arisman $^{3}$, Azi Faiz Ridlo ${ }^{4}$, Tatang Iskandar

syamsul@unsur.ac.id

\section{RESULTS AND DISCUSSION}

After the researcher carried out the pre-cycle test, the researcher analyzed the test to get the pre-cycle test results or initial conditions, the highest score of student difficulty was 5 and the lowest was 0 with an average score of 20.9 from achieving a maximum score of 100 . The percentage of dictation seen from the initial code pronounced at $3.12 \%$. This indicates that learning outcomes are still far from successful, and the results can also be seen in the following diagram:

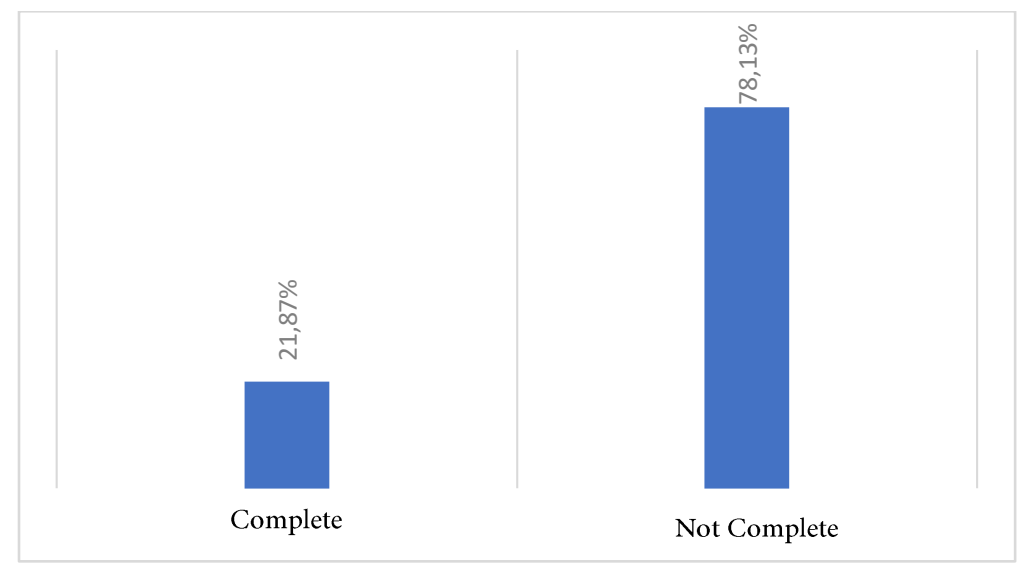

Figure 1.

Lay up engineering skill score percentage (pre-cycle)

By looking at the results achieved in the pre-cycle and the results of reflection, it can be concluded that the learning outcomes are not as expected. This is because students in learning still use methods that are less precise and less structured and in the learning process there are still shortcomings, namely in working time and facilities and learning media that are lacking and can be said to be less varied. So that teachers who provide explanations and guidance to students seem in a hurry, as a result, the learning objectives are not achieved as they should be. Process time and facilities or learning media that are not a good result in teachers being less able to guide their students well in carrying out learning.

\section{Cycle I. Results of student observations}

From the observation sheet Analysis to students obtained data, learning outcomes have not been completed as it is. This is due to several factors, one of which is that there are students who do not pay attention when the teacher explains the layup material and there are still some students who have not been able to answer the teacher's questions about the layup technique properly. like some students who are less serious in learning. 
Improve Learning Outcomes Of Basketball Lay Up Shoot In Junior High School

Muhamad Syamsul Taufik ${ }^{1 *}$, Soleh Solahuddin ${ }^{2}$, Arisman $^{3}$, Azi Faiz Ridlo ${ }^{4}$, Tatang Iskandar

syamsul@unsur.ac.id

This is reinforced when doing lay up exercises, some students have not been able to do it well.

\section{Learning outcomes}

Based on the results of the Cycle I test, the highest score was 7 and the lowest score was 2 with an average value of 48.75 from a maximum achievement of 100 . The percentage of submissions seen from the first cycle reached $21.87 \%$. This indicates that the learning outcomes have not been fully said to be good even though they are better than the pre-cycle test results. These results can also be seen in the following diagram:

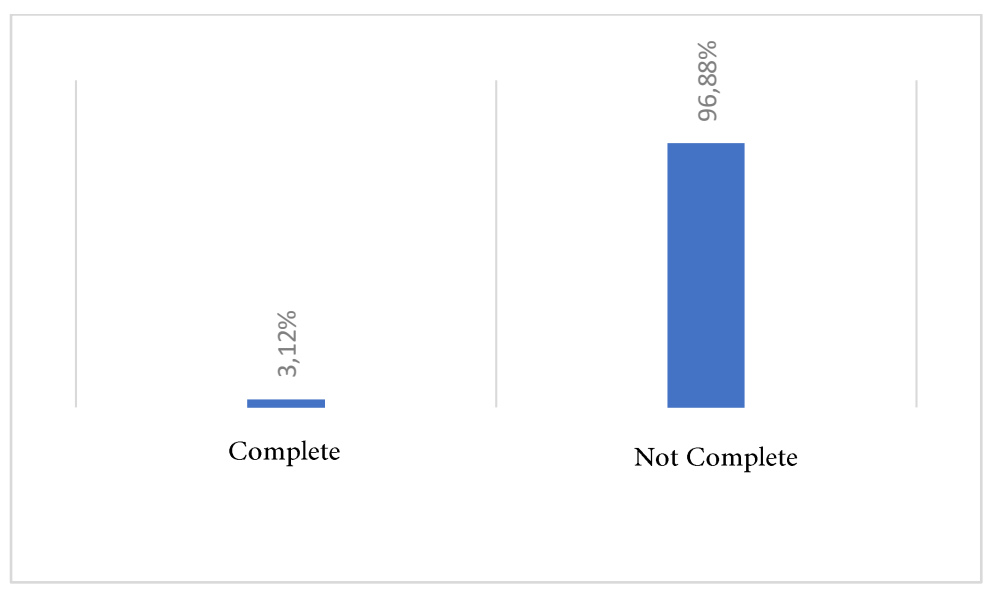

Figure 2.

Percentage of skill scores Lay up Cycle I Evaluation and reflection

Based on the results of observations on students and the results of the evaluation, it can be seen that in the first cycle it cannot be said to be successful because there are still students who have not obtained scores above the minimum compensation value. By looking at the results that have been achieved in the first cycle and the results of reflection, it can be seen that the learning in each group has not been carried out properly and the student's mastery in implementing the basic lay-up techniques and in learning using these methods. The implementation of learning has not been carried out properly, and in the learning process, there is still not enough time management. As a result, the learning objectives are not achieved as expected.

In addition to the above factors, other factors influence, namely there are still many students who are less enthusiastic in the learning process, so that when the explanation of the implementation instructions does not capture the material presented well and its implementation is hampered because the quality of the technique is still not good. 
Improve Learning Outcomes Of Basketball Lay Up Shoot In Junior High School

Muhamad Syamsul Taufik ${ }^{1 *}$, Soleh Solahuddin ${ }^{2}$, Arisman $^{3}$, Azi Faiz Ridlo ${ }^{4}$, Tatang Iskandar

syamsul@unsur.ac.id

\section{Cycle II. Results of observations on students}

Based on the results of student observations, the following results were obtained: Students improve their jumping ability in the lay-up technique through the section method. in the group, as well as when the test showed improvement. Collaboration between students is increasing in improving lay-up technical skills through the section method. Students' courage in conducting lay-up technical tests is increasing. Students have mastered the lay-up technique through methods to improve hand movements and jump in the lay-up technique. Students can coordinate good lay-up movements through the section method. Learning outcomes Based on the results of the second cycle test, the results for the highest 7 points and the lowest 3 points with an average value of 73.1 out of a maximum score of 100 were obtained. The percentage of completeness interpreted reached $81.25 \%$, this shows the results of the basketball lay-up technique test through the parts. goes well.

It can also be seen from the following diagram:

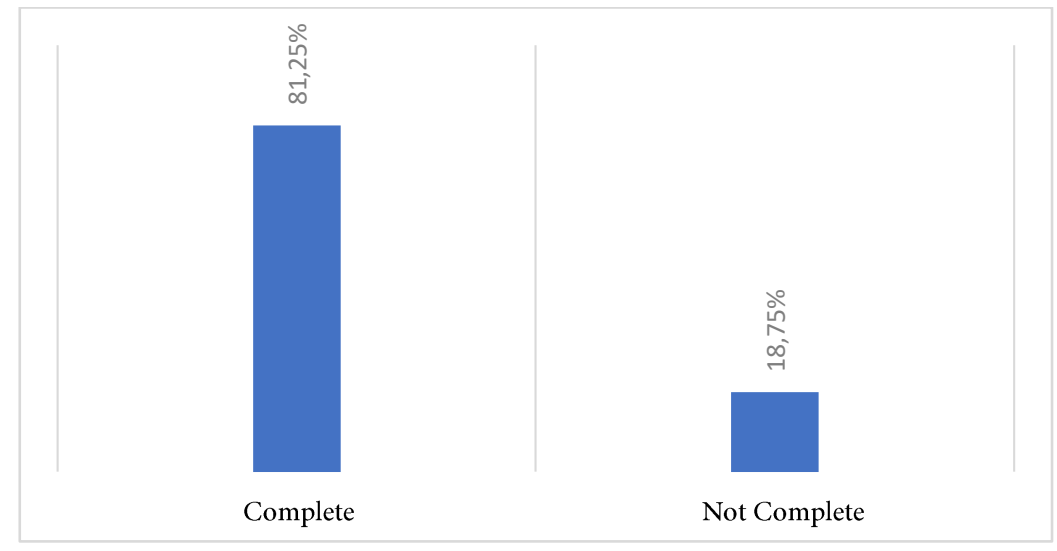

Figure 3.

Percentage Value of Technical Skills Cycle II Layer Evaluating (Reflecting).

The researcher reflects on the implementation of cycle II and analyzes it to conclude the implementation of improving basic basketball lay-up technical skills through the section method at SMP Negeri 1 Ciawi Bogor.

The learning outcomes in the implementation of the second cycle showed an increase in basketball lay-up technique skills. In the first cycle, the percentage of student observation scores was $71.8 \%$, while in the second cycle the student observation scores were $88.15 \%$. This increase is because each individual during the learning process uses the section method to improve basketball lay-up skills, students carry out their learning 
Improve Learning Outcomes Of Basketball Lay Up Shoot In Junior High School

Muhamad Syamsul Taufik ${ }^{1 *}$, Soleh Solahuddin ${ }^{2}$, Arisman $^{3}$, Azi Faiz Ridlo ${ }^{4}$, Tatang Iskandar ${ }^{5}$

syamsul@unsur.ac.id

seriously and confidently.

Based on the teacher's observations, it can be seen that the results of student observations and evaluations in cycle II can be said to be successful because many students get scores above the minimum completeness, so the average student has reached the limit.

And the results of this study obtained grades VII-8 SMP Negeri 1 Ciawi Bogor can be described as follows in diagram 4. namely an increase in the percentage of completeness in each cycle.

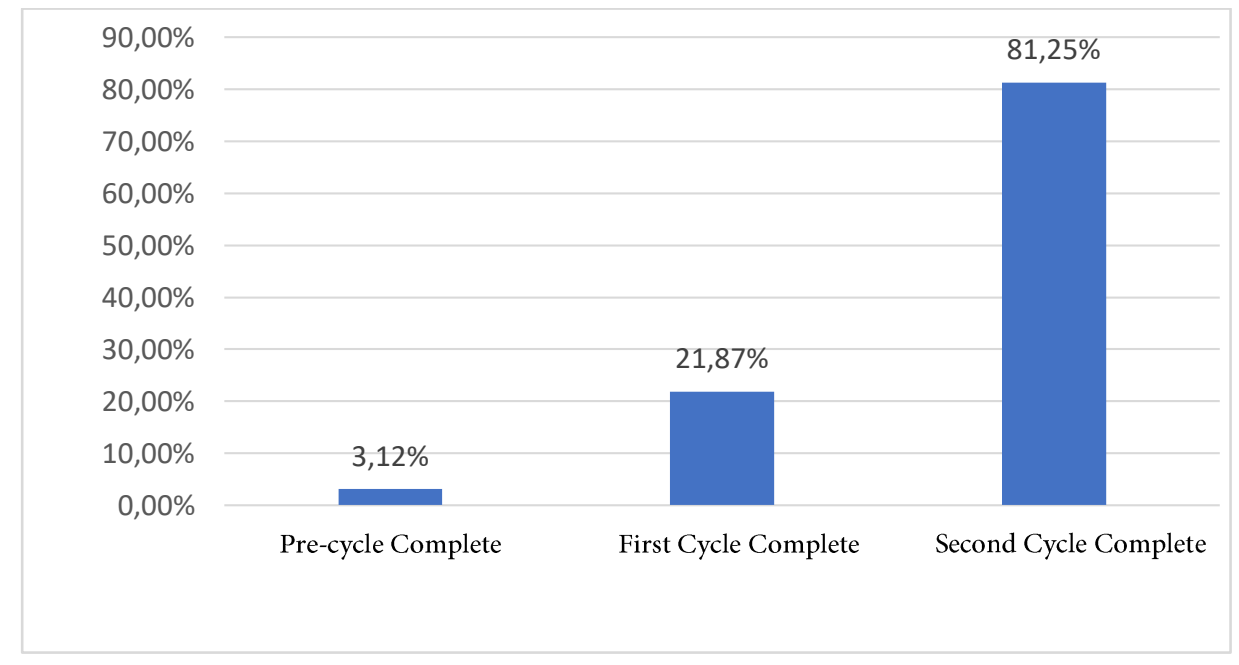

Figure 4.

Percentage of completion on average in each cycle

From diagram 4. we can see the increase in lay-up technique skills, this data is obtained from the analysis of the test results for each cycle. From the results of the analysis, it is known that the improvement of basketball lay-up technique skills through the section method is increasing. After processing and analyzing research data, this section will discuss the results and research findings. The discussion will focus on the problems that have been described previously in chapter I. The learning outcomes of basic basketball lay-up technique skills through the part method have increased in each cycle. For pre-cycle learning outcomes (initial conditions) the average evaluation test score is 20.9 from achieving a maximum score of 100 this happens because students' ability to lay up technical skills is still minimal both in terms of stepping, On the one hand, it is neutral towards the ability to start explosively, (Setiawan et al., 2017) jumps, hand movements and results as well as the teacher's role in time management that has not been fully running well so that when carrying out and carrying out coaching to students it seems rushed, but it is also caused by teachers who are still very minimal and 
Improve Learning Outcomes Of Basketball Lay Up Shoot In Junior High School

Muhamad Syamsul Taufik ${ }^{1 *}$, Soleh Solahuddin ${ }^{2}$, Arisman $^{3}$, Azi Faiz Ridlo ${ }^{4}$, Tatang Iskandar

syamsul@unsur.ac.id

not enough to better support students' abilities in the process of learning lay up techniques in basketball. (Alimuddin, 2017) The perfection of the basic technique is very decisive because it will determine the overall motion. In the first cycle, the average score of the test or overall evaluation was 48.75 , this happened because the students were carrying out the lay-up technique learning process through the section method. It has not gone well so that the mastery of the material is still not understood by students as a result, when carrying out tests or evaluations they have not been able to carry out basketball lay-up techniques properly and correctly both technically and results.

\section{CONCLUSIONS AND SUGGESTIONS}

In Cycle II the average score of students increased dramatically to 73.1 from achieving a maximum score of 100 . This indicates that students are getting used to learning lay-up techniques through the parts method so that the knowledge gained is increased and when carrying out tests or evaluation of most students can do the lay-up of basketball technical skills both technically and results using the learning method at SMP Negeri 1 Ciawi Bogor with the hash above can be improved by the sectional learning method can improve the lay-up of basketball up shoot learning outcomes in school junior secondary.

\section{REFERENCES}

Ahmadi, N. (2007). Panduan olahraga bola voli / Nuril Ahmadi ; Editor: Didin.

Alimuddin, F. D. (2017). The Development of Soft Ball Sport Through Toss Ball Training in The Athlete Soft Ball. Journal of Physical Education, Sport, Health and Recreations, 6(2), 133-139. http://journal.unnes.ac.id/sju/index.php/peshr.

Ambarwati, D. R., Widiastuti, W., \& Pradityana, K. (2017). Pengaruh daya ledak otot lengan, kelentukan panggul, dan koordinasi terhadap keterampilan tolak peluru gaya O'Brien. Jurnal Keolahragaan, 207. https://doi.org/10.21831/jk.v5i2.14918.

Fadillah, M., Kusaini, H. ., Dirgantoro, E. W., \& Hamid, A. (2020). The Effect of Three Corner Drill Training Against Futsal Playback Probability. 407(Sbicsse 2019), 96-97. https://doi.org/10.2991/assehr.k.200219.026.

Gall, M. D., Gall, J. P., \& Borg, W. R. (2003). Epdf.Pub_Educational-Research-anIntroduction-7Th-Edition.Pdf.

Ganang Purnomo Aji. (2016). Pengembangan alat ladder untuk latihan koordinasi, kelincahan dan power (pp. 1-50). 
Improve Learning Outcomes Of Basketball Lay Up Shoot In Junior High School

Muhamad Syamsul Taufik ${ }^{1 *}$, Soleh Solahuddin ${ }^{2}$, Arisman $^{3}$, Azi Faiz Ridlo ${ }^{4}$, Tatang Iskandar ${ }^{5}$

syamsul@unsur.ac.id

Hambali, S. (2019). Implementasi Metode Bermain Dalam Pembelajaran Passing Bawah Bola Voli Di Sekolah Dasar. Perspektif Ilmu Pendidikan, 33, 27-32. Https://Doi.Org/10.21009/Pip.331.3.

Haqiyah, A., Mulyana, M., Widiastuti, W., \& Riyadi, D. N. (2017). The Effect Of Intelligence, Leg Muscle Strength, And Balance Towards The Learning Outcomes Of Pencak Silat With Empty-Handed Single Artistic. Jetl (Journal Of Education, Teaching And Learning), 2(2), 211. Https://Doi.Org/10.26737/Jetl.V2i2.288.

Izhar, A. (2018). Model Kelincahan Pada Siswa Taman Kanak-Kanak Http://Journal.Unj.Ac.Id/Unj/Index.Php/Jpud, 12, 164-174.

Jatmika, H. M. (2015). Pemanfaatan Media Visual Dalam Menunjang Pembelajaran Pendidikan Jasmani Di Sekolah Dasar. Jurnal Pendidikan Jasmani Indonesia, 3(1), 89-99.

Permendikbud No 37. (2018). Permendikbud No 37 Tahun 2018 Tentang Standar Isi Pjok. 1, $1-6$.

Prasetya Et Al., T. D. (2018). Juara: Jurnal Olahraga. Juara: Jurnal Olahraga, 3(2). Http://Jurnal.Upmk.Ac.Id/Index.Php/Juara

Rahadian, A. (2018). Mengembangkan kemampuan Lari Jarak Pendek ( 100 M ) Mahasiswa Pjkr unsur ( Kinovea Software ). Maenpo, 8(1), 1.

Saputri, N. I., Pendidikan, J., Kesehatan, J., \& Keolahragaan, F. I. (2013). Journal Of Physical Education, Sport,. 2(11), 712-717.

Setiawan, H., Tangkudung, J. W., \& Syarif, A. (2017). The Impact Agility Training Toward Dribbling Ability Of Futsal Beginners Player. Journal Of Physical Education, Sport, Health And Recreations, 6(2), 133-139. Http://Journal.Unnes.Ac.Id/Sju/Index.Php/Peshr.

Taufik, M. S. (2018). Meningkatkan Teknik Dasar Dribbling Sepakbola Melalui Modifikasi Permainan. Jurnal Maenpo: Jumal Pendidikan Jasmani Kesehatan Dan Rekreasi, 8(1), 26.

Widiastuti, \& Pramudito Hutomo. (2018). Meningkatan Keterampilan Lompat Jauh Gaya. 09(01), 56-67.

Yuniarto, A., Supriyadi, S., \& Sudjana, I. N. (2018). Pengembangan Media Pembelajaran Berbasis Mobile Learning Teknik Dasar Dan Peraturan Permainan Futsal. Jp.Jok (Jurnal Pendidikan Jasmani, Olahraga Dan Kesehatan), 2(1), 5162.https://Doi.Org/10.33503/Jpjok.V2i1.188. 